\title{
Sequences mediating the translation of mouse S16 ribosomal protein mRNA during myoblast differentiation and in vitro and possible control points for the in vitro translation
}

\author{
Mark L. Hammond, ${ }^{1,4}$ William Merrick, ${ }^{2}$ and Lewis H. Bowman ${ }^{1,3}$ \\ ${ }^{1}$ Department of Biological Sciences, University of South Carolina, Columbia, South Carolina 29208 USA; ${ }^{2}$ Department of \\ Biochemistry, School of Medicine, Case Western Reserve University, Cleveland, Ohio 44106 USA
}

The translation of ribosomal protein (r-protein) mRNAs is generally inefficient and regulated during the differentiation of mouse myoblasts into fibers. In this discussion we show that the first 31 nucleotides of the S16 r-protein mRNA, when located at the $5^{\prime}$ end of the mRNA, are sufficient to impart the translational properties of an r-protein mRNA to the SV-GALK mRNA, which is normally translated efficiently in both myoblasts and fibers. If the same $\mathrm{S16}$ sequences are located within the interior of the 5 '-untranslated region of the SV-GALK mRNA, however, they do not impart the translational properties of an r-protein mRNA to the SV-GALK mRNA. The translation of mouse r-protein mRNAs was examined in vitro to help elucidate the mechanisms controlling their translation. Mouse r-protein mRNAs are inefficiently translated in rabbit reticulocyte extracts, and the same sequences that mediate their inefficient and regulated translation during myoblast differentiation also mediate their inefficient translation in a position-dependent manner in reticulocyte extracts. To determine whether the subpolysomal r-protein mRNAs that are not actively translated in vivo are capable of translation, subpolysomal RNA was translated in reticulocyte extracts. The subpolysomal r-protein mRNAs are just as capable of translation as are polysomal mRNAs. To help identify the initiation factors and/or the steps in the initiation pathway that mediate the inefficient translation of r-protein mRNAs, reticulocyte extracts were supplemented with purified initiation factors. Only eIF-4F, the cap-binding complex, and eIF-3, which is involved in subunit dissociation and interacts with eIF-4F during initiation, stimulated the translation of r-protein mRNA. These experiments, along with $\mathbf{m}^{7} \mathrm{GDP}$ inhibition studies, suggest that eIF-4F and/or eIF-3, or the steps mediated by these factors, mediate the inefficient translation in reticulocyte extracts and raise the possibility that these steps also control the regulated translation of r-protein mRNAs during myoblast differentiation.

[Key Words: Ribosomal protein; translation; myoblast differentiation]

Received April 29, 1991; revised version accepted June 28, 1991.

The synthesis of eukaryotic ribosomal proteins (r-proteins) is regulated at the level of translation in a wide variety of organisms, including Dictyostelium (Steel and Jacobson 1987), Drosophila (Al-Atia et al. 1985), Xenopus (Pierandrei-Amaldi et al. 1982; Baum and Wormington 1985), chicken (DePhilip et al. 1980), and mouse (Geyer et al. 1982; Agrawal and Bowman 1987; Meyuhas et al. 1987). The synthesis of $r$-proteins may be regulated translationally so that their synthetic rates can be altered rapidly in response to external or internal stimuli. Alternatively, the translational regulation of $\mathbf{r}$-proteins

\footnotetext{
${ }^{3}$ Corresponding author.

${ }^{4}$ Present address: Los Alamos National Laboratory, LS-4, MS. M888, Los Alamos, New Mexico 87545 USA.
}

may facilitate the coordination of r-protein and rRNA synthesis. However, the widespread use of translational control to regulate r-protein synthesis strongly suggests that this control mechanism is important for ribosome synthesis.

We have observed both a developmental (Agrawal and Bowman 1987) and a hormonal (Hammond and Bowman 1988) control of $r$-protein mRNA translation during the differentiation of mouse MM14DZ myoblasts into fibers. In culture, mouse myoblasts divide rapidly and then withdraw from the cell cycle and fuse to form multinucleated skeletal muscle fibers (Hauschka et al. 1979). During this differentiation, ribosome formation decreases about threefold owing to a coordinate decrease in the synthesis of both rRNA and r-proteins (Agrawal and 
Bowman 1987; Bowman 1987a). The reduced synthesis of $r$-proteins is regulated to a large extent at the level of mRNA translation. We have also shown that insulin rapidly stimulates the translation of $r$-protein mRNAs in myoblasts but not fibers (Hammond and Bowman 1988).

The translation of $r$-protein mRNA is generally inefficient and regulated during myoblast differentiation. Changes in the translation of r-protein mRNA in developing muscle cells are due to alterations in the fraction of mRNA molecules that associate with polysomes rather than to changes in the number of ribosomes translating each r-protein mRNA (Agrawal and Bowman 1987; Hammond and Bowman 1988). About $50-60 \%$ of r-protein mRNAs associate with polysomes and are actively translated in myoblasts, and insulin increases this percentage to $\sim 75-80 \%$. In fibers, the percentage of r-protein mRNA that associates with polysomes decreases to $\sim 25-30 \%$ regardless of whether insulin is added to the culture medium. However, the $r$-protein mRNAs associated with polysomes are translated by the approximate theoretical maximum number of ribosomes in both myoblasts and fibers (Kafatos 1972). In contrast, $>95 \%$ of actin and p31 mRNAs associate with polysomes in both myoblasts and fibers.

The mechanisms regulating the translational control of eukaryotic r-protein mRNAs are largely unknown. Inhibitor studies (Craig and Perry 1971; Warner 1977) and dosage compensation experiments (Abovich et al. 1985; Pierandrei-Amaldi et al. 1985; 1988; Warner et al. 1985; El Baradi et al. 1986; Bowman 1987b; Rhoads and Roufa 1987; Baum and Wormington 1988; Maicas et al. 1988; Tsay et al. 1988) indicate that the translation of eukaryotic r-protein mRNA is not controlled by negative feedback inhibition as in Escherichia coli (Nomura et al. 1984). It is not known whether the regulated translation of r-protein mRNAs is mediated by changes in the structure of the mRNAs rendering some mRNAs incapable of translation or by changes in the activities of translation initiation factors or other factors, either inhibitory or stimulatory. Analysis of the translation of r-protein mRNA in an in vitro translation system would help distinguish between these possibilities and facilitate the identification of factors that mediate the inefficient and regulated translation of $\mathbf{r}$-protein mRNAs. In this discussion we show that r-protein mRNAs are inefficiently translated in rabbit reticulocyte extracts. We have used this system to show that subpolysomal r-protein mRNAs are capable of being translated and to help identify initiation factors and/or the steps in the translation initiation pathway that are involved in the inefficient translation of r-protein mRNAs in vitro.

The r-protein mRNAs must contain sequences that endow them with the specific translational properties of being inefficiently translated and translationally regulated. Identification of these regulatory sequences is important in understanding how the translation of $\mathbf{r}$-protein mRNAs is controlled and will also facilitate identification and analysis of the factors that mediate the translation of r-protein mRNAs. Our experiments show that the first 31 nucleotides of the S16 r-protein mRNA 5'- untranslated region are sufficient to impart the translational properties of an r-protein mRNA to a heterologous mRNA in a position-dependent manner.

\section{Results}

To identify sequences that mediate the inefficient and regulated translation of S16 r-protein mRNA during mouse myoblast differentiation, chimeric plasmids were constructed between plasmids containing the mouse S16 r-protein and the SV-GALK genes (Fig. 1). The SV-GALK parental plasmid contains the SV40 early promoter linked to the bacterial GALK-coding region followed by the polyadenylation site from the bovine growth hormone gene (Pfarr et al. 1986). The parental SV-GALK plasmid and each chimeric plasmid were cotransfected into myoblasts, along with pSV2-neo, which contains a gene for resistance to the antibiotic G418 (Southern and Berg 1982). G418-resistant colonies (20-100) were pooled and analyzed further. The steady-state levels of the mRNAs derived from the chimeric genes were estimated to be 0.2-2.0 times the level of endogenous S16 mRNA. This relatively small amount of mRNA should not interfere with the endogenous translation mechanisms. The translational efficiencies of the mRNAs were inferred from their distribution in polysome gradients. Figure 2 shows that $>95 \%$ of the mRNA derived from the SV-GALK parental plasmid associates with polysomes in both myoblasts and fibers, indicating that it is efficiently translated. In contrast, the endogenous S16 r-protein mRNA (Agrawal and Bowman 1987), as well as S16 mRNA derived from transfected genes (Bowman 1987b), is inefficiently translated. Only $\sim 60 \%$ of the $\$ 16$ mRNA associates with polysomes in myoblasts, and this percentage decreases to $\sim 25 \%$ in fibers (Fig. 2 ).

\section{The first 31 nucleotides of $S 16$ r-protein $m R N A$ mediate its inefficient and regulated translation only if located at the $5^{\prime}$ end of the mRNA}

Two chimeric plasmids were initially constructed whose derived mRNAs contain S16 r-protein mRNA sequences either at the $5^{\prime}$ or the $3^{\prime}$ end /Fig. 1 ; Materials and methods). The mRNA derived from the first plasmid, S16GALK, contains the first 31 nucleotides of the 54-nucleotide S16 mRNA 5'-untranslated spacer at its $5^{\prime}$ end, followed by GALK $5^{\prime}$-untranslated sequences, the GALK-coding region, and the bovine growth hormone polyadenylation sequences. The mRNA derived from the second plasmid, SV-S16, contains SV40 sequences at its $5^{\prime}$ end, followed by the last 19 nucleotides of the S16 $5^{\prime}$-untranslated region and the remainder of the $\$ 16$ mRNA sequence (Fig. 1). Primer extension analyses suggest that the $5^{\prime}$ end of the chimeric S16-GALK mRNA is identical to the $5^{\prime}$ end of the endogenous S16 mRNA (data not shown).

The translational efficiencies of the chimeric S16GALK and SV-S16 mRNAs in myoblasts and fibers were inferred from their distributions in polysome gradients with specific hybridization probes as described in Mate- 

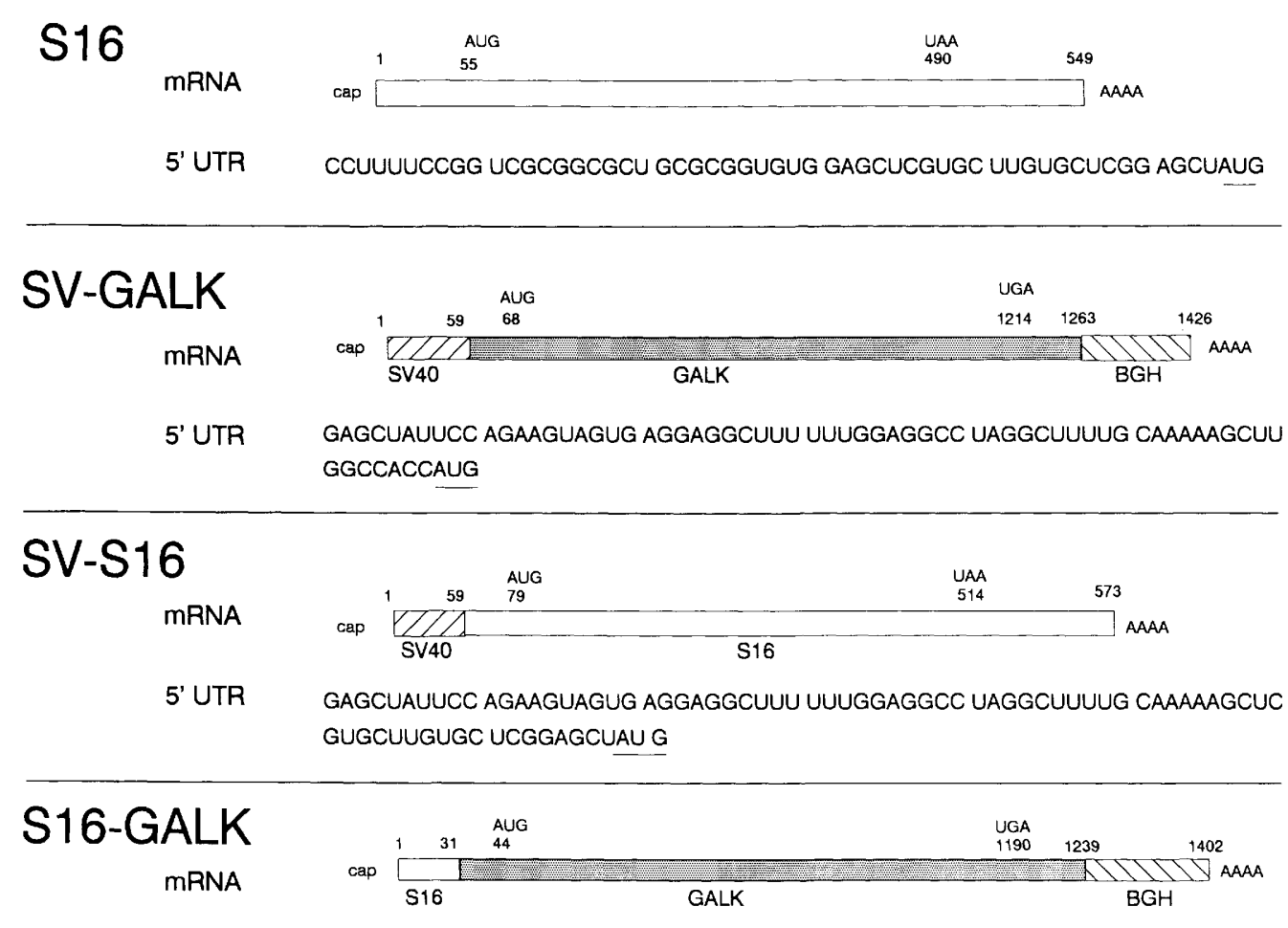

5' UTR CCUUUUCCGg UCGCGgCGCu gCgCggugug gagCuUgGCC ACCAUG

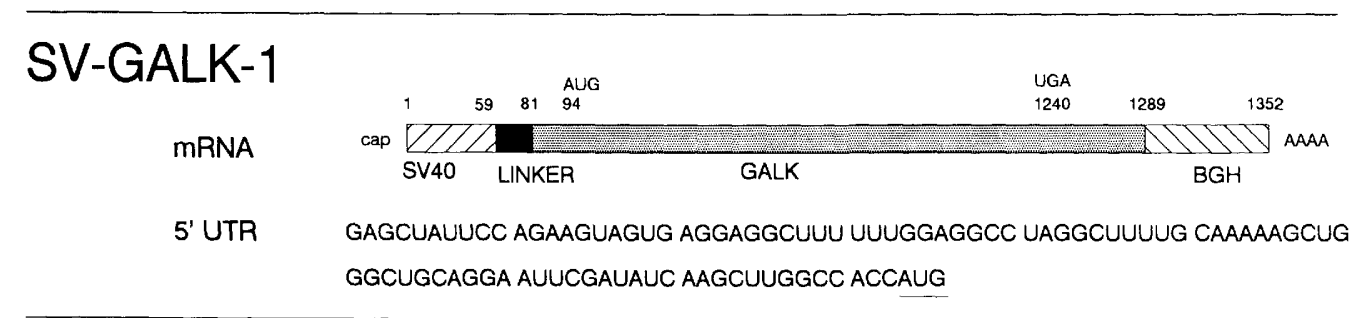

\section{SV-S16-GALK \\ mRNA}

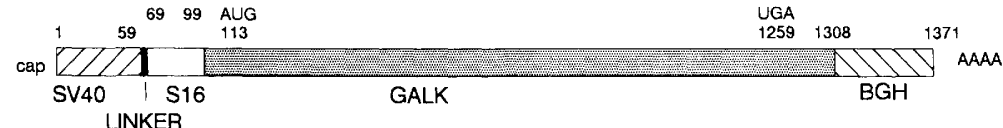

5' UTR

GAGCUAUUCC AGAAGUAGUG AGGAGGCUUUU UUUGGAGGCC UAGGCUUUUG CAAAAAGCUG GGCUGCAGCC UUUUCCGGUC GCGGCGCUGC GCGGUGUGGA AGCUUGGCCA CCAUG

Figure 1. Structures of the chimeric mRNAs used to identify the sequences controlling the translation of $r$-protein mRNAs. The structures of the actual plasmids are described in Materials and methods. (BGH) Bovine growth hormone sequence that contains the polyadenylation signals. (5' UTR) The $5^{\prime}$-untranslated region. The initiator AUG is underlined. The linker is derived from pBS SK (-) (see Materials and methods).

rials and methods. Figure 2 shows that the S16-GALK mRNA, which contains only the first 31 nucleotides of the S16 mRNA, is distributed between nontranslating subpolysomal messenger ribonucleoproteins (mRNPs) and polysomes in myoblasts, and that the fraction associated with polysomes decreases after myoblasts differentiate into fibers such as the S16 mRNA (Fig. 2). In contrast, $>95 \%$ of the SV-S16 mRNA, which contains SV40 sequences at its $5^{\prime}$ end, is associated with polysomes in both myoblasts and fibers. Therefore, the first
31 nucleotides of $\$ 16$ mRNA are sufficient to confer the translational properties of an r-protein mRNA to a heterologous mRNA.

To determine whether the first 31 nucleotides of the S16 r-protein mRNA must be located at the $5^{\prime}$ end of the mRNA to impart the translational properties of an r-protein mRNA to a heterologous mRNA, additional chimeric plasmids were constructed. A new SV-GALK parental plasmid, SV-GALK-1, was constructed that has a polylinker region within its $5^{\prime}$-untranslated region to fa- 

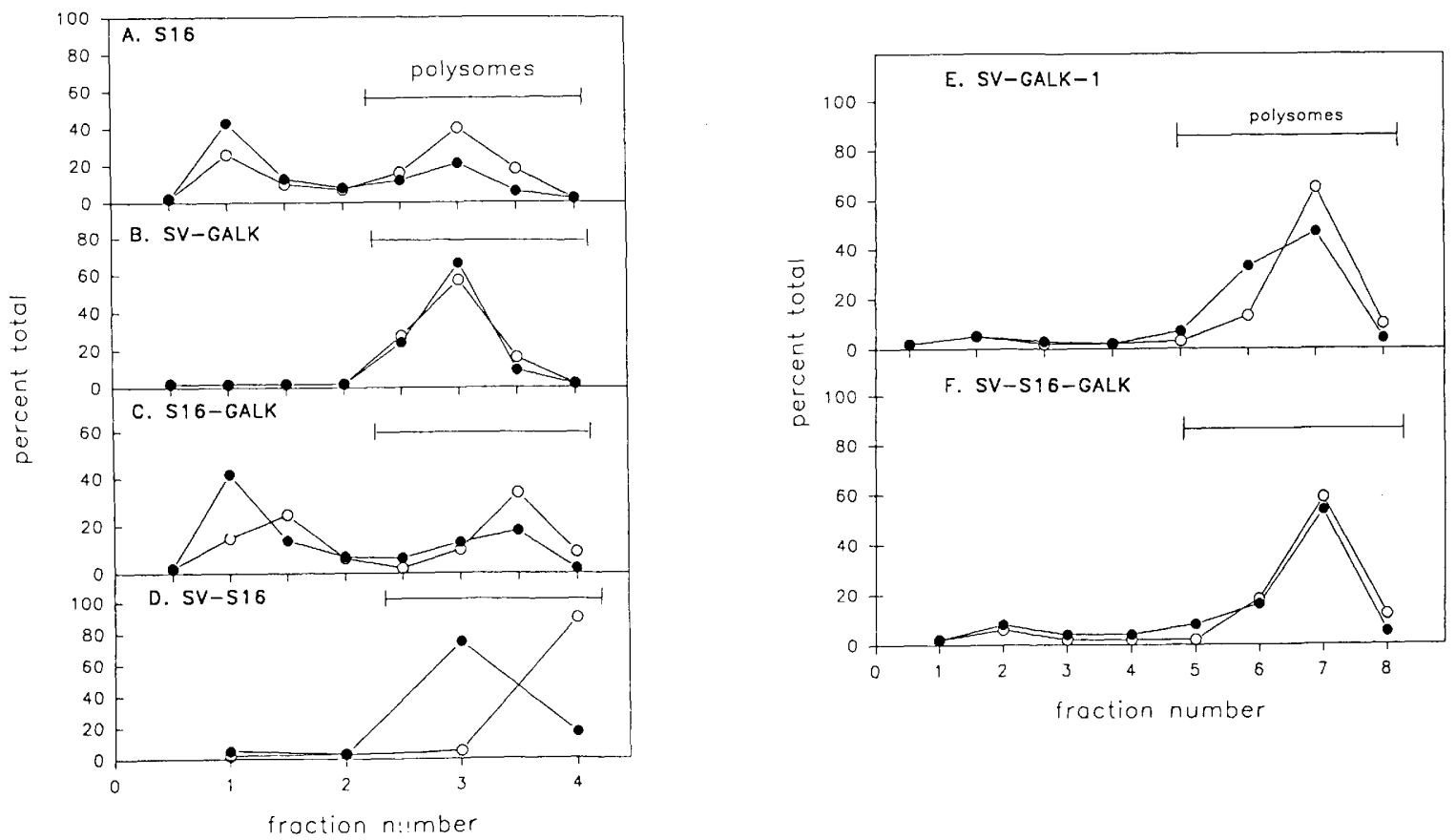

Figure 2. Polysomal distribution of $S 16$, SV-GALK, S16-GALK, SV-S16, SV-GALK-1, and SV-S16-GALK mRNAs in myoblasts and fibers. Cytoplasmic extracts from the indicated cell lines were fractionated on sucrose gradients to separate polysomes from subpolysomal structures. RNA was isolated from fractions of the gradient, and the relative amount of the indicated mRNA was determined by using hybridization analyses, as described in Materials and methods. The distribution of actin and endogenous S16 mRNAs in each gradient was also determined. In each case, $>95 \%$ of the actin mRNA was associated with polysomes, and the endogenous S16 mRNA was distributed $(A)$. $(O)$ Myoblasts; $(O)$ fibers.

cilitate cloning of oligonucleotides into the interior of the 5'-untranslated region (Fig. 1; Materials and methods). An oligonucleotide containing the first 31 nucleotides of the S16 mRNA was cloned into the polylinker creating the plasmid SV-S16-GALK (Fig. 1). The SVS16-GALK plasmid and the new parental SV-GALK-1 plasmid were transfected into myoblasts as described above. Primer extension analyses suggest that the mRNAs derived from both of these plasmids start at a major SV40 cap site at coordinate 5230 (Benoist and Chambon 1981). Figure 2 shows that the mRNAs derived from both the SV-GALK-1 and the SV-S16-GALK plasmids are efficiently translated in myoblasts and fibers, as $>95 \%$ of these mRNAs associate with polysomes. Therefore, the first 31 nucleotides of the S16 mRNA do not impart the translational properties of an r-protein mRNA to a heterologous mRNA when they are located internally within the 5 '-untranslated region.

\section{$r$-Protein $m R N A$ s are translated inefficiently in vitro}

To facilitate analysis of the factors that mediate the translation of r-protein mRNAs, mouse fiber RNA was translated in rabbit reticulocyte extracts, and the translational efficiencies of $r$-protein mRNAs and control mRNAs were inferred from their distribution in polysome gradients. There is some background hybridization for L32 r-protein mRNA in the absence of added fiber RNA (Fig. 3). However, this migrates faster than the mouse L32 mRNA and does not interfere with measurements of the distribution of added mouse L32 r-protein mRNA. Figure 3 shows that only $30-40 \%$ of L18, L32, and S16 r-protein mRNAs are associated with polysomes. This value for the polysomal association of r-protein mRNAs ranges from $15 \%$ to $40 \%$ from experiment to experiment, depending on the extract used. The r-protein mRNAs associate with polysomes containing two to five ribosomes, which is slightly less than the theoretical maximum of four to six ribosomes for mRNAs of this size (Kafatos 1972). The remainder of the r-protein mRNAs is associated with subpolysomal mRNPs and is not translated. In contrast, $>90 \%$ of actin and p31 (Theodor et al. 1985) mRNAs associate with polysomes in reticulocyte extracts, similar to the situation in vivo (Fig. 3). Therefore, the relative translational efficiencies of r-protein mRNAs and control mRNAs in vivo are faithfully reproduced in reticulocyte extracts.

Additional experiments were performed to further characterize the in vitro translation system. Figure 3 shows that poly $(\mathrm{A})^{+}$RNA and whole-cell RNA from fibers are translated with equal efficiencies in vitro. This result indicates that the inefficient translation of r-protein mRNAs is not due to inhibitory RNAs in the poly $(\mathrm{A})^{-}$fraction. Figure 3 also shows that $\mathrm{r}$-protein mRNAs are translated inefficiently, and control mRNAs are translated efficiently over at least a fivefold range of poly $(\mathrm{A})^{+}$mRNA concentration. Similar results are obtained with whole-cell fiber RNA (data not shown). The 


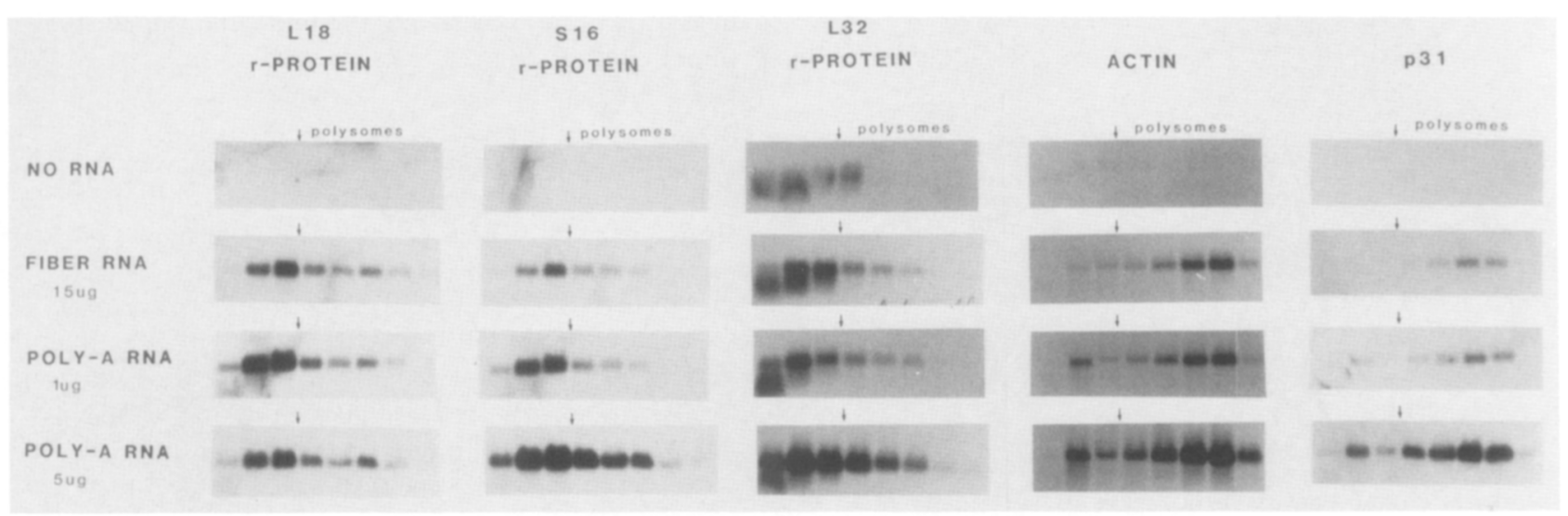

Figure 3. RNA gel blot analyses of polysome gradients from reticulocyte lysate translation reactions. The indicated amounts of whole-cell or poly $(\mathrm{A})^{+}$fiber RNA were added to $100-\mu \mathrm{l}$ translation reactions. Translation reactions were layered on sucrose density gradients and fractionated into nonpolysomal and polysomal fractions. RNA was isolated from gradient fractions and separated on parallel agarose gels. The resulting duplicate RNA gel blots were hybridized to the indicated probes to determine the distribution of specific mRNAs. Gel lanes to the right of the arrow indicate polysomal fractions of the gradient.

translational efficiencies of these mRNAs are not sensitive to differences in $\left[\mathrm{K}^{+}\right]$in the translation reactions over the tested range of $60-120 \mathrm{~mm}$ (data not shown).

To determine whether the polysome assay for measuring translational efficiency of r-protein mRNAs in vitro is valid, several translational inhibitors were added to the in vitro system. Translation reactions containing whole-cell fiber RNA were incubated for $10 \mathrm{~min}$ to allow polysome formation and then incubated with EDTA, puromycin (Nathan 1964), or ATA (Lodish et al. 1971) for an additional $5 \mathrm{~min}$. All three inhibitors cause the disruption of polysomes for actin and L18, L32, and S16 r-protein mRNAs (data not shown). Sensitivity to EDTA indicates that the association of mRNAs with polysomesized particles is $\mathrm{Mg}^{2+}$ dependent, implying that the mRNAs are in bona fide polysomes. The inhibition by puromycin indicates that the polysomal ribosomes are elongating and not stalled, as puromycin causes premature chain termination and dissociation of elongating ribosomes (Nathan 1964). ATA is an inhibitor of initiation (Lodish et al. 1971). In reticulocyte extracts it takes $\sim 120$ sec to complete a hemoglobin chain. If ribosome elongation of r-proteins is occurring at a similar rate, then polysomes should dissociate shortly after initiation is blocked by addition of ATA. Greater than $85 \%$ of the actin and r-protein polysomes dissociated after $5 \mathrm{~min}$ of ATA treatment. These experiments indicate that mRNAs cosedimenting with polysomes are actively being translated by ribosomes.

\section{The first 31 nucleotides of $S 16 \mathrm{mRNA}$ also mediate its inefficient translation in reticulocyte extracts}

To determine whether similar sequences mediate the inefficient translation of S16 r-protein mRNA in vivo and in vitro, whole-cell RNA was isolated from fibers of SVGALK, SV-GALK-1, S16-GALK, SV-S16, and SV-S16GALK cell lines and translated in rabbit reticulocyte ex- tracts. Figure 4 shows that mRNAs that have SV40 sequences at their $5^{\prime}$ ends are efficiently translated in reticulocyte extracts. Greater than $95 \%$ of the parental SV-GALK-1 mRNA, SV-S16 mRNA, and SV-S16GALK mRNA associate with polysomes. The SV-GALK mRNA is also translated efficiently in vitro (data not shown). In contrast, the S16-GALK mRNA, which has S16 sequences at its $5^{\prime}$ end, is inefficiently translated in reticulocyte extracts. Only $\sim 20 \%$ of this S16-GALK mRNA associates with polysomes, similar to the fraction of the endogenous S16 mRNA that associated with polysomes in this translation reaction. Therefore, the same 31 nucleotides that mediate the inefficient and regulated translation of $\mathbf{r}$-protein mRNAs in a position-dependent manner during myoblast differentiation also mediate their inefficient translation in a position-dependent manner in reticulocyte extracts.

\section{Most nontranslating $r$-protein $m R N A$ s are found in $45 S \mathrm{mRNPS}$ in myoblasts, fibers, and reticulocyte extracts}

Previous experiments indicate that nontranslating r-protein mRNAs associate with particles smaller than $80 \mathrm{~S}$. However, the precise size of this subpolysomal r-protein mRNP was unknown. To determine the size of the subpolysomal particles, myoblasts and fibers, as well as reticulocyte-translation reactions, were fractionated on high-resolution sucrose gradients. Figure 5 shows that there are two subpolysomal r-protein mRNPs in myoblasts and fibers: a minor one sedimenting at $\sim 15 \mathrm{~S}$ and another at $\sim 45 \mathrm{~S}$. The size of these mRNPs in relation to ribosomal subunits is insensitive to the salt concentration in the range of $0.1-0.5 \mathrm{M}$ and the presence of heparin to $1 \mathrm{mg} / \mathrm{ml}$ in the gradients (data not shown). Figure 5 also shows that there is a dramatic increase in the relative amount of the $45 \mathrm{~S}$ species after myoblasts differentiate into fibers. Interestingly, the size of the major subpolysomal particle in the in vitro translation reactions is 


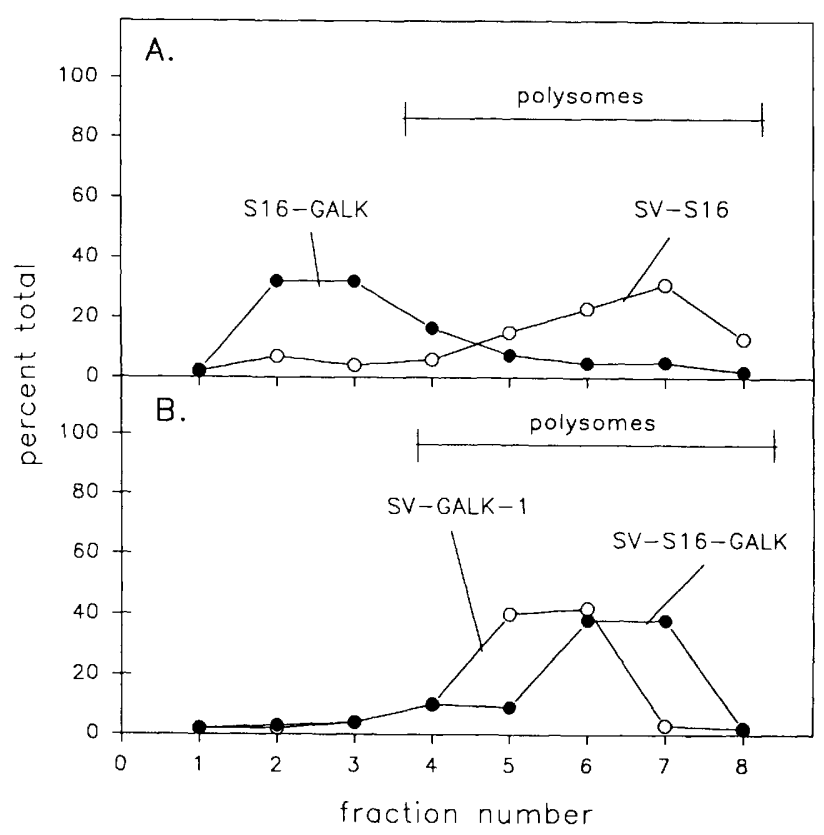

Figure 4. Polysomal distribution of mRNAs translated in the reticulocyte extract. Whole-cell fiber RNA was isolated from the S16-GALK, SV-S16, SV-GALK-1, and SV-S16-GALK transformants and translated in reticulocyte lysates. Translation reactions $(100 \mu l)$ containing $10 \mu \mathrm{g}$ of whole-cell RNA were fractionated on sucrose density gradients. The content of specific mRNAs in gradient fractions was determined by hybridization, as described in Materials and methods. The polysomal region of the gradients is indicated. As a control, the distribution of actin and S16 mRNAs was also determined for each translation; and in each case, $>95 \%$ of the actin mRNA and $20-30 \%$ of the endogenous S16 mRNA associated with polysomes.

also $\sim 45 \mathrm{~S}$ (Fig. 5). Thus, r-protein mRNAs are distributed between $45 \mathrm{~S}$ subpolysomal RNPs and polysomes in reticulocyte extracts similar to the situation in vivo.

\section{$r$-Protein mRNAs associated with $45 S \mathrm{mRNPS}$ are capable of being translated}

It is possible that the nontranslation of subpolysomal r-protein mRNAs is caused by structural deficiencies of these mRNAs. To test functionally whether the r-protein mRNAs in $45 \mathrm{~S}$ mRNPs are capable of translation, RNA was purified from both the nonpolysomal and polysomal portions of sucrose gradients derived from muscle fiber cultures and translated in vitro. About $20-25 \%$ of both the polysomal and subpolysomal S16 r-protein mRNAs associated with polysomes in the reticulocyte extracts (data not shown). In a parallel translation reaction $\sim 20-25 \%$ of S16 r-protein mRNA in whole-cell fiber RNA also associated with polysomes. The similar translatability of these mRNAs in vitro suggests that they are equally capable of being translated.

We have also examined the translatabilty of polysomal and subpolysomal mRNAs isolated from fibers treated with low doses of cycloheximide. Low doses of cyclo- heximide slow elongation without affecting initiation, thereby increasing the number of ribosomes per mRNA and shifting functional, nonrepressed subpolysomal mRNAs into polysomes. We have shown previously that the percentage of $r$-protein $\mathrm{mRNAs}$ associated with subpolysomal particles in fibers decreases from $\sim 75$ to $25 \%$ after a 30-min incubation with a low dose of cycloheximide (Agrawal and Bowman 1987). These results suggest that at least two-thirds of $r$-protein mRNAs normally in subpolysomal complexes are functional in vivo. If a nonfunctional class of $r$-protein mRNAs does exist, the mRNA associated with subpolysomal mRNPs in cycloheximide-treated cells should be enriched for these nonfunctional mRNAs. To determine whether the subpolysomal r-protein mRNAs remaining after cycloheximide treatment are functional, subpolysomal and polysomal RNAs were purified from gradients of cycloheximidetreated fibers and translated in vitro. Figure 6 shows that a slightly smaller fraction of the subpolysomal mRNAs associates with polysomes as compared with the mRNA isolated from polysomes, and this result is reproducible.

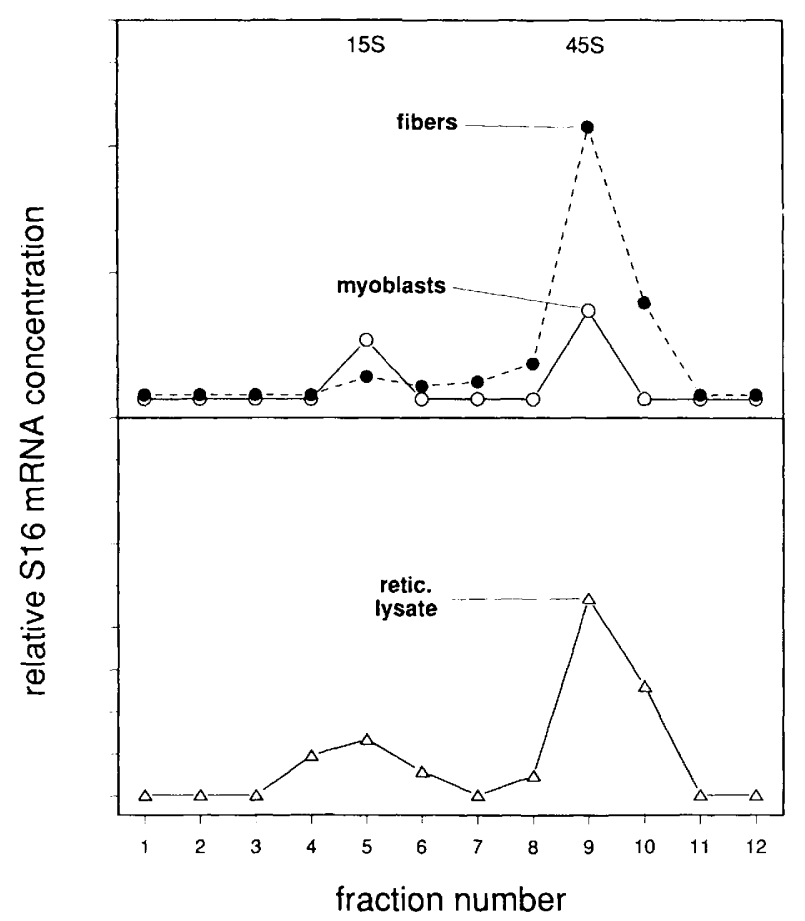

Figure 5. Size of S16 mRNPs in myoblasts, fibers, and the reticulocyte lysate translation system. Myoblast and fiber extracts and a 50- $\mu$ l reticulocyte reaction containing $5 \mu \mathrm{g}$ of muscle fiber RNA were centrifuged for $5 \mathrm{hr}$ at $45,000 \mathrm{rpm}$ in an SW55 rotor to display the smaller particles. Myoblast and fiber gradients were analyzed by RNA gel blot analyses, and the in vitro translation gradient was fast blotted as described in $\mathrm{Ma}$ terials and methods. The distribution of S16 mRNA was quantitated by densitometric scanning of the resulting autoradiograms and was normalized to reflect the proportion of S16 mRNA that is typically not associated with polysomes in each system. The sedimentation values were extrapolated from the sedimentation of $40 \mathrm{~S}$ and $60 \mathrm{~S}$ subunits. 


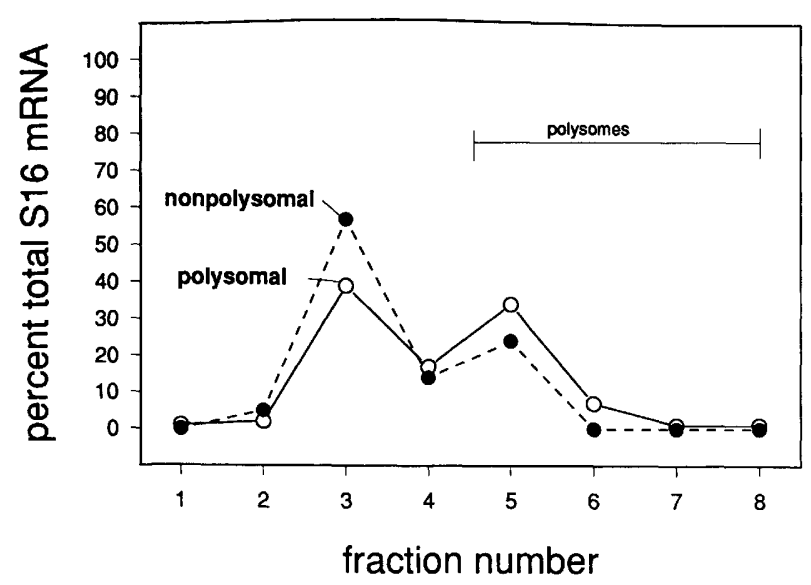

Figure 6. Translation of nonpolysomal and polysomal RNA in vitro. RNA was isolated from the nonpolysomal and polysomal regions of gradients derived from fiber cultures that had been treated with $8 \times 10^{-7} \mathrm{M}$ cycloheximide for $30 \mathrm{~min}$ before harvesting. Purified nonpolysomal and polysomal RNAs were translated in vitro $(10 \mu \mathrm{g} / 100-\mu \mathrm{l}$ reaction). The translational efficiency of S16 was determined by RNA gel blot analyses and densitometric analyses. Polysomal fractions are indicated.

This difference is not large, however, and these experiments suggest that the vast majority of the subpolysomal mRNAs remaining after cycloheximide treatment are fully capable of being translated.

\section{In vitro translation of $S 16 r$-protein $m R N A$ is preferentially inhibited by $\mathrm{m}^{7} G D P$}

To determine whether the translation of $\mathrm{r}$-protein mRNAs is cap dependent, the cap analog $\mathrm{m}^{7} \mathrm{GDP}$ was included in in vitro translation reactions. Whole-cell fiber RNA was translated in the presence and absence of $\mathrm{m}^{7} \mathrm{GDP}$ in anisomycin-inhibited reactions, and the association of specific mRNAs with $80 \mathrm{~S}$ initiation complexes was determined by sucrose gradient sedimentation and hybridization analyses. Anisomycin inhibits elongation and traps all mRNAs that have initiated during the reaction into $80 \mathrm{~S}$ initiation complexes. $\mathrm{m}^{7} \mathrm{GDP}$ inhibits the formation of mRNA : cap-binding protein complexes and presumably makes cap-binding proteins limiting in the reaction. The amount of $\mathrm{m}^{7} \mathrm{GDP}(1 \mathrm{~mm})$ used in these experiments was not completely inhibitory so that the relative competition of specific mRNAs for cap-binding factors could be determined. Figure 7A shows that the association of S16 r-protein mRNAs with $80 \mathrm{~S}$ initiation complexes is completely inhibited by $\mathrm{m}^{7} \mathrm{GDP}$ in vitro. In contrast, the association of actin and p31 mRNAs with 80 S initiation complexes is only partially inhibited by $\mathrm{m}^{7} \mathrm{GDP}$, with actin mRNA being inhibited slightly more than p31 mRNA (Fig. 7B,C). Thus, the hierarchy of $\mathrm{m}^{7} \mathrm{GDP}$ inhibition from most sensitive to least sensitive is S16 mRNA, actin mRNA, and p31 mRNA. These results suggest that S16 r-protein mRNA translation is cap dependent and that $r$-protein mRNAs are poor competitors for cap-binding proteins. Figure 7, B and $\mathrm{C}$, shows that submonosomal actin and $\mathrm{p} 31$ mRNAs associate with $25 \mathrm{~S} \mathrm{mRNPs}$ in $\mathrm{m}^{7} \mathrm{GDP}$-inhibited reactions. Therefore, these nontranslating particles are not similar to the $45 \mathrm{~S}$ subpolysomal r-protein mRNPs described previously. Interestingly, submonosomal particles containing r-protein mRNAs generated by $\mathrm{m}^{7} \mathrm{GDP}$ inhibition in vitro sediment at $45 \mathrm{~S}$. Thus, these r-protein mRNPs differ from those formed with the efficiently translated mRNAs and are identical in size to the major nontranslating mRNP observed in vivo and in vitro (see Fig. 5). However, it is not known whether these RNPs contain the same proteins.

\section{eIF-4F and eIF-3 stimulate S16 r-protein mRNA translation in vitro}

To help identify the factors that mediate the translation of $r$-protein mRNAs and/or the steps in the initiation pathway where this regulation occurs, reticulocyte extracts were supplemented with purified initiation factors and the translational efficiencies of S16 r-protein and actin mRNAs were measured (for reviews on translation initiation, see Moldave 1985; Pain 1986; Hershey 1989). If $r$-protein mRNAs are translated inefficiently because a specific initiation factor is limiting in our reactions, then supplementation with this factor should relieve this inhibition. Alternately, if an inhibitor blocks the action of an initiation factor, then supplementing the reaction with this initiation factor might overcome this block. In these experiments, several different concentrations of each initiation factor were added to the extracts, and the translational efficiencies of S16 and actin mRNAs were inferred from their distribution in polysome gradients. The results reported here are derived from reactions that contained the maximum concentration of each purified initiation factor that was not inhibitory to the translation of actin mRNA (Fig. 8).

Several of the initiation factors tested did not stimulate the translation of S16r-protein mRNA. The addition of eIF-1A (which binds to 40S subunits before mRNA binding and stabilizes $43 \mathrm{~S}$ and $48 \mathrm{~S}$ complexes), eIF-2 (which facilitates GTP-dependent tRNA ${ }^{\text {Met }}$ binding to 43S ribosomal subunits), eIF-4A and eIF-4B (which facilitate unwinding of mRNA secondary structure), and eIF$5 \mathrm{~A}$ /which is thought to stimulate ribosomal subunit joining) did not increase significantly the fraction of $\mathrm{S} 16$ mRNA associated with polysomes (Fig. 8B,C). The small stimulation by eIF-4A and eIF-4B observed in Figure 8, B and $C$, is only for one fraction in these gradients and is not reproducible. Thus, these results suggest that the inefficient translation of $\mathbf{r}$-protein mRNAs is not regulated by these translation initiation factors or the steps they mediate.

Two initiation factors, eIF-3 and eIF-4F, significantly and reproducibly stimulate the translation of S16 r-protein mRNA (Fig. 8A). eIF-3 has ribosomal subunit dissociation activity and is required for mRNA binding to the $43 \mathrm{~S}$ initiation complex. eIF- $4 \mathrm{~F}$ is the cap-binding protein complex and is required for the efficient translation of capped mRNAs. eIF-4F also appears to be a major dis- 
A.

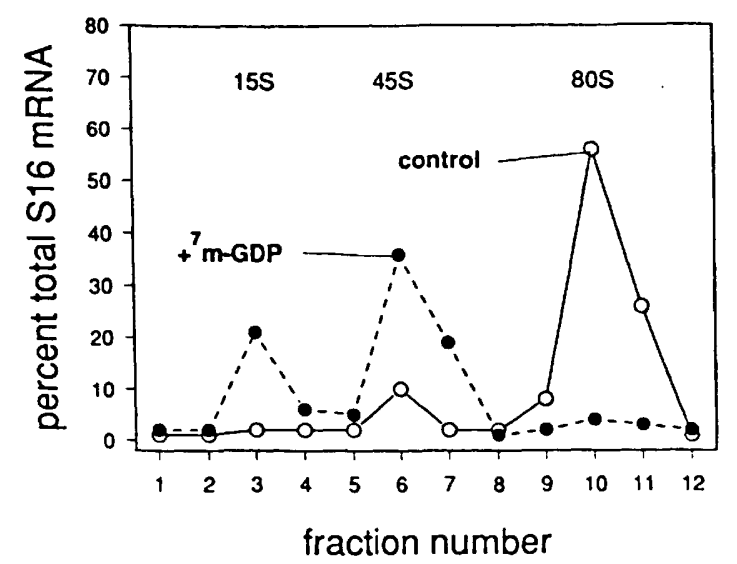

B.

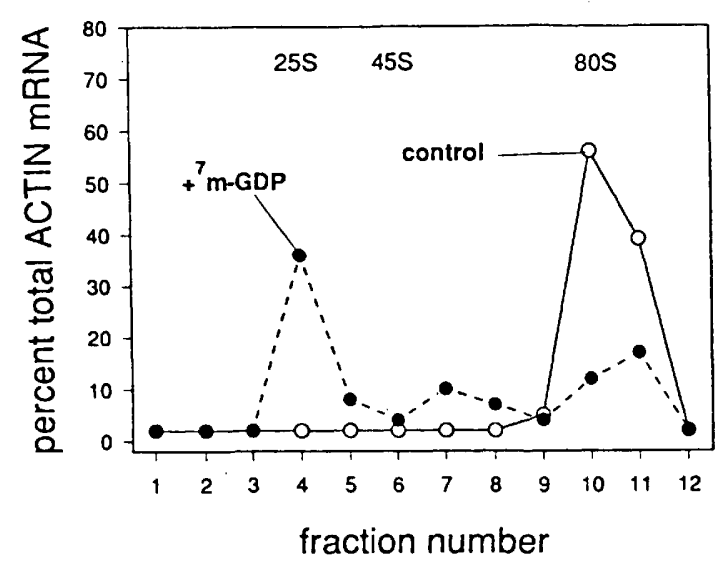

C.

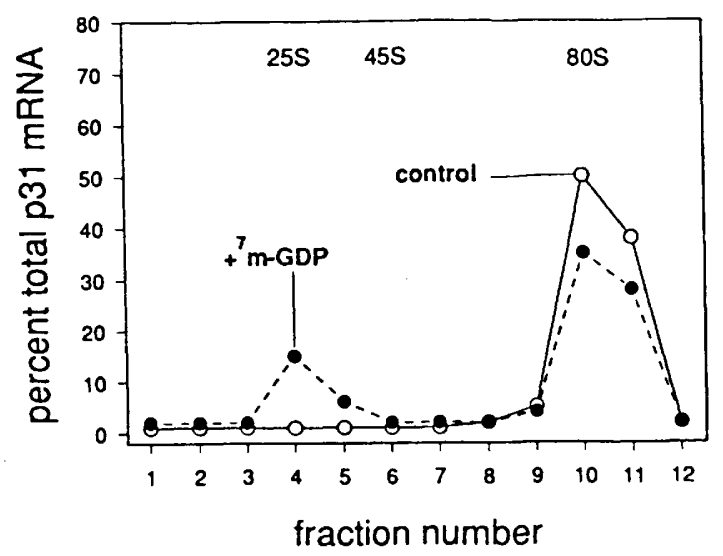

Figure 7. The effect of $\mathrm{m}^{7} \mathrm{GDP}$ on the association of $\mathrm{S} 16$, actin, and $\mathrm{p} 31 \mathrm{mRNAs}$ with $80 \mathrm{~S}$ initiation complexes in vitro. The association of S16 r-protein mRNAs, control actin, and p31 mRNAs with $80 \mathrm{~S}$ initiation complexes in the presence and absence of $1 \mathrm{~mm}$ $\mathrm{m}^{7} \mathrm{GDP}$ was determined by translating $5 \mu \mathrm{g}$ of S16-G fiber wholecell RNA (Bowman 1987b) in 50- $\mu$ l reticulocyte translation reactions containing $0.5 \mathrm{mg} / \mathrm{ml}$ of anisomycin. Translation reactions were fractionated on sucrose density gradients, and the distribution of the indicated mRNAs was determined by hybridization analyses and densitometric scanning of the resulting autoradiograms. The percentage of the specific mRNAs for each fraction is indicated for S16 r-protein mRNAs $(A)$, actin mRNAs $(B)$, and p31 mRNAs $(C)$. Gradients in these experiments were centrifuged for $4 \mathrm{hr}$. The indicated sedimentation values were extrapolated from the migration of $40 \mathrm{~S}, 60 \mathrm{~S}$, and $80 \mathrm{~S}$ ribosomal subunits as observed in the optical density profile of each gradient.

criminatory factor involved in the selective translation of specific mRNAs (Ray et al. 1983). These experiments raise the possibility that eIF-3 and/or eIF-4F, or the steps that they mediate, are involved in the translational regulation of r-protein mRNAs.

The translational efficiencies of mRNAs were also measured in elongation-inhibited reactions, and the association of mRNAs with $80 \mathrm{~S}$ initiation complexes was assayed. None of the initiation factors reproducibly increased the fraction of $\mathrm{S} 16 \mathrm{r}$-protein mRNAs associated with $80 \mathrm{~S}$ initiation complexes (data not shown). This could be because the elongation-inhibited reactions trap all mRNAs that have initiated during the reaction into $80 S$ complexes and do not assay the rate of initiation. In contrast, whether an mRNA is found in polysomes is dependent on its rate of initiation and rate of elongation. The rate of elongation is generally assumed to be similar for all mRNAs. Therefore, the polysome measurements reflect rates of initiation. It is possible that a kinetic analysis of $80 \mathrm{~S}$ initiation complex formation, which would measure initiation rates, would have detected differences among the factors. In our experimental condi- tions, however, $80 \mathrm{~S}$ complexes form very rapidly (within $2 \mathrm{~min}$ ), making a kinetic analysis difficult.

\section{Discussion}

Our results indicate that the first 31 nucleotides of the 5 '-untranslated region of S16 r-protein mRNA are sufficient to confer the translational properties of being inefficiently translated and translationally regulated to a heterologous mRNA. Other experiments also point to the importance of the $5^{\prime}$ leader in controlling the translation of $\mathbf{r}$-protein mRNAs in Xenopus (Mariottini and Amaldi 1990) and in lymphosarcoma cells (Levy et al. 1991). It is possible that the control region actually extends several nucleotides beyond the first 31 nucleotides of the S16 r-protein mRNA, because the adjoining vector sequences are similar to the corresponding S16 mRNA sequence. Our results show that the control region is considerably upstream (23 nucleotides) of the S16 initiator AUG, indicating that the AUG context is not involved in the inefficient and regulated translation of r-protein mRNAs. Furthermore, our experiments show 
A.

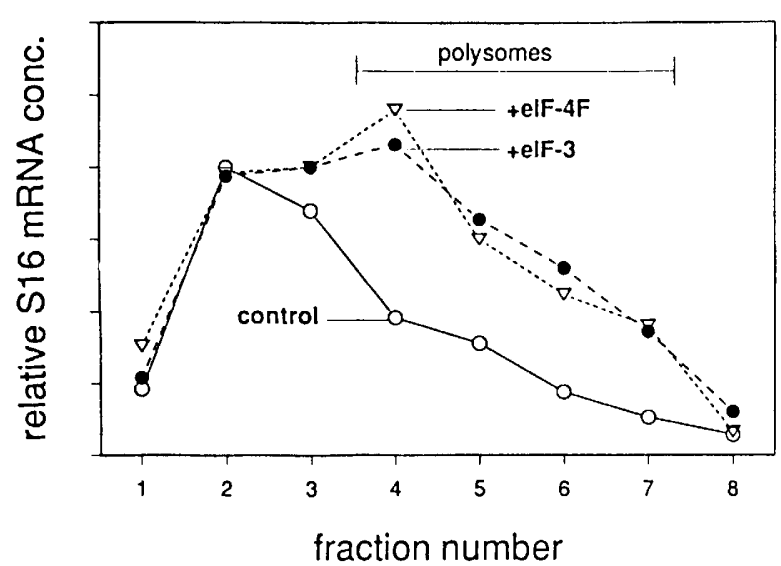

C.

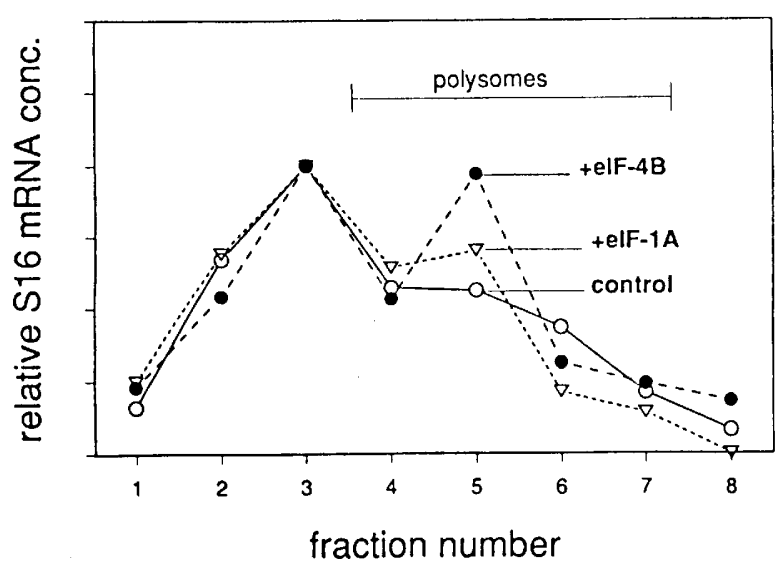

B.

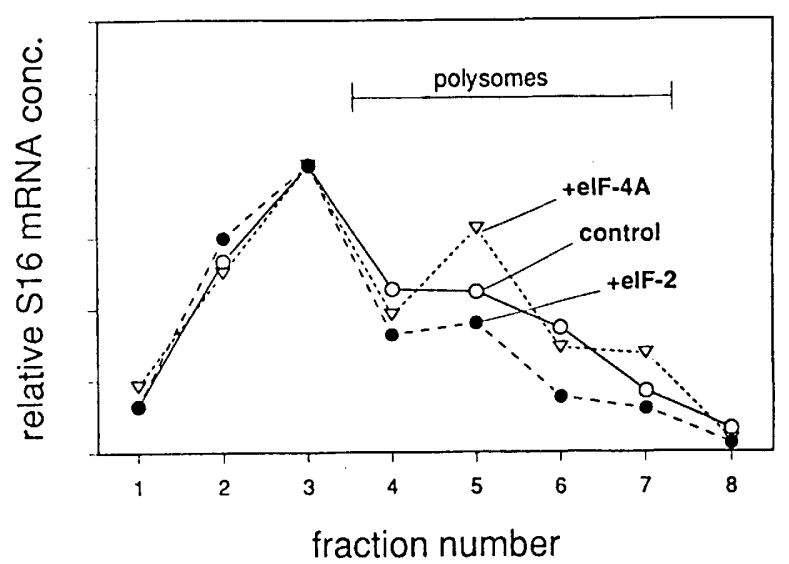

D.

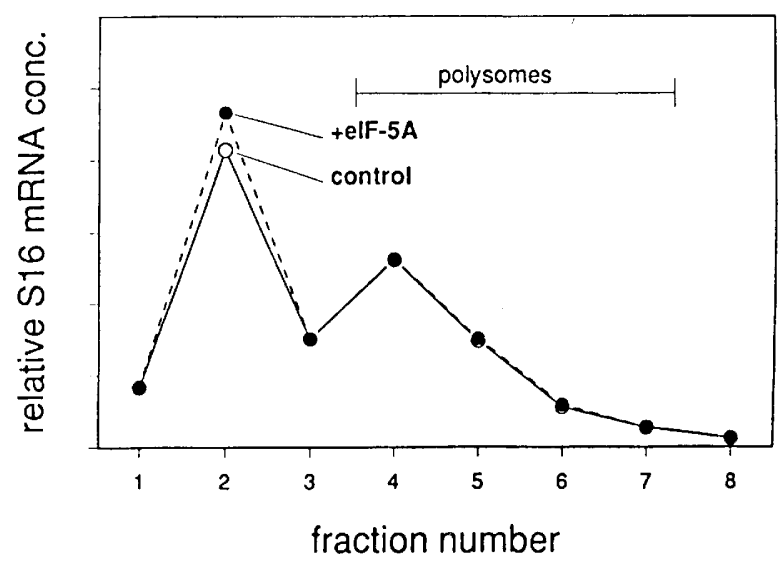

Figure 8. The effect of purified initiation factor supplementation on the association of S16 r-protein mRNA with polysomes in reticulocyte extracts. Purified initiation factors were added to $25-\mu \mathrm{l}$ translation reactions containing $2.5 \mu \mathrm{g}$ of S16-G fiber whole-cell RNA in the following amounts: $(A)$ eIF-3, $1.37 \mu g_{\text {; }}$ eIF-4F, $230 \mathrm{ng}$; $(B)$ eIF-2, $512 \mathrm{ng}$; eIF-4A $1.43 \mu g_{\text {; }}(C)$ eIF-4B, $600 \mathrm{ng}$; eIF-1A, $950 \mathrm{ng}$; $(D)$ eIF-5A, $520 \mathrm{ng}$. The extracts were fractionated on sucrose gradients, and the relative amounts of S16 r-protein and actin mRNAs in each fraction were determined by dot blot hybridization analyses (see Materials and methods). The distribution of S16 mRNAs was quantitated by densitometric scanning of the resulting autoradiograms. To aid in visualizing the data the nonpolysomal fraction containing the largest amount of S16 mRNA was set equal to 1 and the values of the other fractions were adjusted proportionally. Thus, these plots do not reflect the absolute amount of mRNA but, rather, the distribution of S16 in relation to this nonpolysomal fraction. Each panel represents a different experiment. Greater than $90 \%$ of actin mRNA was associated with polysomes in each experiment shown.

that the effect of these 31 nucleotides on the translation of a heterologous mRNA is position dependent. When this sequence is located within the $5^{\prime}$-untranslated region instead of at the $5^{\prime}$ end, it fails to confer the translational properties of an r-protein mRNA to the heterologous mRNA.

It is not known whether the primary structure of the translational control region is important for the inefficient and regulated translation of r-protein mRNAs. The first 8-12 nucleotides of mouse r-protein mRNAs are pyrimidine rich, and the next $15-30$ nucleotides are GC rich (Dudov and Perry 1984; Wiedemann and Perry 1984; Wagner and Perry 1985). Either of these features could be important for the inefficient and regulated translation of r-protein mRNAs. Disruption of the polypyrimidine tract does cause the r-protein mRNAs to be translated efficiently (Levy et al. 1991). Furthermore, previous studies indicate that capped $(\mathrm{U}, \mathrm{C})_{n}$ ribopolymers do not readily form $80 S$ initiation complexes (Both et al. 1976). However, all studies to date have indicated structural or presumed structural specificity and not sequence specificity. 
Features of the secondary or tertiary structure of the first 31 nucleotides of the S16 mRNA may specify the translational properties of r-protein mRNAs. Previous experiments indicate that relatively stable secondary structures located within the $5^{\prime}$-untranslated regions of mRNAs inhibit translation (e.g., Pelletier and Sonenberg 1985; Lawson et al. 1986; Kozak 1988, 1989a,b). Interestingly, the effect of the secondary structures on translation displays positional effects similar to that detected here for the first 31 nucleotides of S16 mRNAs. These stable secondary structures are more inhibitory when they are located within $\sim 10$ nucleotides of the cap site. For example, a moderately stable secondary structure $(\Delta \mathrm{G}=-30 \mathrm{kcal})$ inhibited translation only when positioned near the $5^{\prime}$ end of the message and only under certain conditions of stress (Kozak 1988, 1989a). Computer analyses of the first 30-36 nucleotides of S16, L32, and L30 r-protein mRNAs indicate that stems of similar stability ( $\Delta \mathrm{G}$ of about $-9 \mathrm{kcal}$ ) are possible in all these mRNAs. However, these possible stems are considerably less stable than those reported previously to affect the translation of eukaryotic mRNAs. Further experimentation is required to determine the role of primary versus secondary structure in controlling the inefficient and regulated translation of $\mathbf{r}$-protein mRNAs.

Analysis of the translation of r-protein mRNAs in vitro showed that $r$-protein mRNAs are translated inefficiently and are distributed between polysomes and $45 \mathrm{~S}$ subpolysomal mRNPs in reticulocyte extracts as in vivo. In addition, the same sequences that mediate the inefficient and regulated translation of $r$-protein mRNAs in vivo also mediate the inefficient translation of r-protein mRNAs in vitro in a position-dependent manner. Knowledge of the factors and steps mediating the inefficient translation of r-protein mRNA is important, because it is likely that these same steps control the regulation of r-protein mRNA translation that occurs during muscle development and in other systems.

Our results show that the r-protein mRNAs associated with subpolysomal $45 \mathrm{~S}$ mRNPs and with polysomes in developing muscle cells are equally capable of being translated. This result suggests that changes in the distribution of r-protein mRNAs between subpolysomal mRNPs and polysomes, which occur during myoblast differentiation, are not due to alterations in the mRNA primary structure that effect the translatability of these mRNAs. Therefore, regulation of $r$-protein mRNA translation must be due to alterations in the activity of stimulatory or inhibitory factors.

Two types of experiment suggest that the steps mediated by eIF-4F are involved in the inefficient translation of $r$-protein mRNAs in vitro. First, the addition of eIF-4F to reticulocyte extracts stimulates the translation of S16 $r$-protein mRNA. Second, $\mathrm{m}^{7} \mathrm{GDP}$, which inhibits formation of the eIF-4F-mRNA complex, preferentially inhibits the translation of S16 r-protein mRNAs, suggesting that $\mathrm{r}$-protein mRNAs are poor competitors for cap-binding proteins. Interestingly, in $\mathrm{m}^{7} \mathrm{GDP}$-inhibited translation reactions most $r$-protein mRNAs sediment at
$45 \mathrm{~S}$, which is the size of the nontranslating r-protein mRNPs in uninhibited reactions and in vivo.

It is possible that the translation of $r$-protein mRNAs is regulated by the activity of eIF-4F in a manner specified by the Lodish model (Lodish 1976) or other similar models (Godefroy and Thach 1981). In this model, the translation of mRNAs, which do not compete efficiently for rate-limiting factors, is preferentially depressed when the activity of the factor is reduced. The activity of eIF$4 \mathrm{~F}$ is probably regulated by phosphorylation-dephosphorylation reactions (Joshi-Barve et al. 1990; Morley et al. 1991). Thus, if r-protein mRNAs do not compete well for eIF-4F, as suggested by our experiments, alterations in the phosphorylation of eIF-4F could explain the regulated translation of r-protein mRNAs during muscle development. If such phosphorylation reactions do occur during myoblast differentiation, however, they do not cause a significant change in the overall rate of protein synthesis, as myoblasts and fibers synthesize proteins at similar rates (Agrawal and Bowman 1987). There is a correlation between the phosphorylation of p24 (eIF-4E), a subunit of eIF- $4 \mathrm{~F}$, and the translation of mouse L32 r-protein mRNA in serum-stimulated 3T3 cells (Kaspar et al. 1990). However, it is possible that serum stimulation also affects other factors that are involved in translation. Our results are also consistent with a model where an inhibitor controls the translation of r-protein mRNAs by binding to r-protein mRNAs and preventing their interaction with initiation factors in a manner similar to the inhibition of ferritin mRNA translation (Aziz and Munro 1987; Hentze et al. 1987). Other models are also possible.

Previous studies have implicated the cap-binding complex, eIF-4F, in the control of overall protein synthetic rates (Bonneau and Sonenberg 1987; Duncan et al. 1987; Huang et al. 1987; Lopo et al. 1988) and in the preferential translation of certain mRNAs (Ray et al. 1983). The conditions used in our experiments, however, differ from these earlier experiments. In the earlier experiments (Ray et al. 1983), competitive conditions were established by translating saturating amounts of two mRNAs having different translational efficiencies in a reconstituted translation system. Under these conditions, one mRNA was translated more efficiently than the other. eIF-4F was identified as a factor that relieved competition between the two mRNAs and stimulated the translation of the inefficiently translated mRNA. In contrast, in our translation system, r-protein mRNAs are translated inefficiently under conditions where the system does not appear to be saturated for mRNA (i.e., increasing the RNA concentration 10-fold does not alter the translational efficiencies of control or r-protein mRNAs; data not shown). Thus, although eIF-4F is implicated in both cases, the actual mechanism through which it exerts its influence may be different. However, in vivo where mRNA levels are near saturating (Duncan et al. 1987), a modest reduction in eIF-4F activity would lead to a dramatic reduction in the translation of poorly competitive mRNAs.

The fraction of r-protein mRNAs associated with poly- 
somes is altered in vivo during myoblast differentiation and in vitro by supplementation with eIF-3 or eIF-4F. To explain this polysome distribution of $r$-protein mRNAs we suggest that there is a rate-limiting, regulated step in the initiation process the first time an r-protein mRNA initiates and that subsequent initiations bypass this step. It is possible that the rate-limiting step occurs during the formation of the $48 \mathrm{~S}$ preinitiation complex where eIF-3 and eIF-4F interact or are closely associated. This could explain the observation that both eIF- 3 and eIF-4F stimulate the translation of r-protein mRNAs. However, further experimentation is required to characterize the regulated step and to determine whether changes in the activities of initiation factors or inhibitors actually control the translation of $\mathbf{r}$-protein mRNAs during myoblast differentiation.

\section{Materials and methods}

\section{Cell culture}

MM14DZ mouse myoblasts (Hauschka et al. 1979) were grown as described previously with partially purified fibroblast growth factor (Bowman 1987b). Cultures were fed fresh media $24 \mathrm{hr}$ after passage. Myoblast fusion initiates after $72 \mathrm{hr}$, and by $120 \mathrm{hr}$ $>95 \%$ of the nuclei are within fibers. Myoblasts were harvested at $48 \mathrm{hr}$, and fibers at $120 \mathrm{hr}$ after passage.

\section{Construction of chimeric plasmids}

Chimeric plasmids were constructed between SV-GALK (DSP1BZBGH) (Pfarr et al. 1986) and pS16 (Wagner and Perry 1985) plasmids. The SV-GALK plasmid contains the 356-nucleotide PvuI-HindIII fragment containing the SV40 early promoter linked to the GALK-coding region having an AUG context modified for eukaryotic translation (see Fig. 1). The GALKcoding region is followed by the bovine growth hormone polyadenylation site. The pS16 plasmid contains the entire S16 r-protein gene and flanking regions.

To construct the SV-S16 plasmid, the SV-GALK plasmid was digested with BamHI and HindIII to remove both the GALKcoding region and the bovine growth hormone polyadenylation site, and the ends were filled with reverse transcriptase. The SacI fragment (nucleotides 36-2054) of pS16 (Wagner and Perry 1985) was blunt ended with S1 nuclease and ligated to the above vector. The SV-S16 plasmid contains the SV40 early promoter linked to the first exon of the S16 gene within the 5 '-untranslated regions. This plasmid has the remainder of the downstream S16 gene sequences. The structure of the mRNA derived from this chimeric plasmid is shown in Figure 1.

To generate the S16-GALK plasmid, the SV-GALK plasmid was cut with SmaI and HindIII to remove the SV40 early promoter and the HindIII end was filled with reverse transcriptase. The EcoRI-SacI fragment of pS16 (nucleotides approximately -1100 to +31 ) was blunt ended with S1 nuclease and ligated to the above vector. This S16-GALK plasmid contains the S16 promoter linked to the GALK-coding sequence within the $5^{\prime}$ untranslated regions. The plasmid also contains bovine growth hormone polyadenylation site (for the structure of the mRNA derived from this plasmid, see Fig. 1).

The SV-GALK-1 vector was generated in a two-step process. In the first step, the SV40 promoter from SV-GALK was excised with SmaI and HindIII, and the HindIII end was filled with reverse transcriptase. The promoter was then ligated into the
SmaI site of the plasmid pBS SK(-) (Stratagene). In the next step, the HindIII-Sall fragment of SV-GALK containing $11 \mathrm{nu}-$ cleotides of the 5 '-untranslated spacer, the entire GALK-coding region, and the bovine growth hormone polyadenylation site, was ligated into the HindIII-SalI site of the above vector. This creates a vector of pBS SK (-) containing PstI, EcoRI, EcoRV, and HindIII within the $5^{\prime}$-untranslated region.

The SV-S16-GALK plasmid was constructed by first cleaving SV-GALK-1 within the 5 '-untranslated region with $P_{S t I}$ and HindII and removing the small piece generated. A kinased oligonucleotide containing the first 31 nucleotides of S16 mRNA sequences flanked at one end by sequences complementary to the $5^{\prime}$ overhang of the HindIII site, and flanked on the other end by sequences complementary to the $3^{\prime}$ overhang of the PstI site, was ligated to the above vector at $4^{\circ} \mathrm{C}$. Treatment of the ligation reaction with the Klenow fragment did not improve the yield of transformants. The structures of all plasmid constructs were confirmed by DNA sequencing.

\section{Cell transfection}

Myoblasts were cotransfected with each of the chimeric plasmids and pSV-neo, and stable transformants were selected with G418 as described previously (Bowman 1987b). Two independent sets of transformants, each containing 20-100 colonies, were analyzed for each construct. In every case, the translational efficiencies of the chimeric mRNAs from duplicate sets were identical.

\section{Polysome and RNA isolation}

Myoblast and fiber extracts were fractionated on sucrose gradients as described previously (Agrawal and Bowman 1987; Bowman 1987b; Hammond and Bowman 1988). The gradients were fractionated into eight $0.6-\mathrm{ml}$ fractions. Each $0.6-\mathrm{ml}$ fraction was collected into a $2.0-\mathrm{ml}$ tube containing 0.5 grams of guanidine- $\mathrm{HCl}$ and mixed until dissolved. The tube was then filled to the top with $100 \%$ ethanol, mixed, and stored at $-20^{\circ} \mathrm{C}$ overnight. In trial experiments $>95 \%$ of added tritium-labeled bacterial RNA was quantitatively precipitated using this technique. The pellets were collected by centrifugation, rinsed with $90 \%$ ethanol, pelleted again, and fractionated on RNA gel. Pilot experiments indicate that heparin, which coprecipitates with the RNA in this procedure, does not interfere with the detection of r-protein mRNAs when $<300 \mu \mathrm{g}$ is loaded with the RNA on a lane of the agarose gel.

\section{Hybridization analyses}

Typically, RNAs isolated from polysome gradients were denatured with glyoxal, fractionated on $1 \%$ agarose gels (McMaster and Carmichael 1977), blotted, and hybridized to nick-translated isolated cDNA inserts for S16, L18, L32 (Meyuhas and Perry 1980; Agrawal and Bowman 1987), p31 (Theodor et al. 1985 , or actin mRNA. The actin probe was isolated from a cDNA clone generated in this laboratory to mouse $\alpha$-skeletal muscle actin and cross-hybridizes to all other mouse actins.

For in vitro translation reactions containing anisomycin, a fast blot method of hybridization analysis was developed. In these experiments, RNA was isolated from the fibers of an overproducing transformant line, S16-G, that contains 23 -fold more S16 mRNA than do control fibers (Bowman 1987b). Gradient fractions $(0.6 \mathrm{ml})$ were mixed with an equal volume of $12 \times \mathrm{SSC}$ $(1.8 \mathrm{M} \mathrm{NaCl}, 0.18 \mathrm{M}$ sodium citrate) and $14 \%$ formaldehyde and heated to $65^{\circ} \mathrm{C}$ for $10 \mathrm{~min}$. Aliquots $(50$ and $100 \mu l)$ from each 
sample were applied to Amersham Hybond-N nylon membranes. Volumes $>100 \mu \mathrm{l}$ were determined to be saturating in this assay. The resulting filters were hybridized and rinsed as described (Agrawal et al. 1987) and exposed to Kodak X-Omat AR film with an intensifying screen at $-70^{\circ} \mathrm{C}$. The exposed autoradiographs were quantitated by densitometric analysis on a Helena Quick Scan densitometer to determine the relative hybridized signal in each lane.

The S16-GALK, SV-GALK, SV-GALK-1, and SV-S16-GALK mRNAs were detected by hybridizing a T7 RNA polymerasegenerated (Melton et al. 1984) probe complimentary to the GALK sequences to the RNA gel blots. This probe does not hybridize to control mRNA isolated from nontransfected cells. Hybridization to gel blots from polysomes was as described previously (Agrawal and Bowman 1987), except that the blots were hybridized at $63^{\circ} \mathrm{C}$ and dextran sulfate was omitted. The final rinse of the blot was in $0.1 \times \mathrm{SSC}(15 \mathrm{~mm} \mathrm{NaCl}, 1.5 \mathrm{~mm}$ sodium citrate), $0.2 \%$ SDS, at $63^{\circ} \mathrm{C}$ for $15 \mathrm{~min}$.

The SV-S16 mRNA was detected with an RNase A protection assay (Myers et al. 1985). The hybridization probe was an RNA probe (Melton et al. 1984) complementary to nucleotides 12546 of the S16 mRNA and also contained vector sequences at both ends. The probe was hybridized to RNA overnight at $55^{\circ} \mathrm{C}$ in $50 \%$ formamide, $0.4 \mathrm{M}$ PIPES- $\mathrm{HCl}(\mathrm{pH} 6.8), 0.4 \mathrm{M} \mathrm{NaCl}, 1 \mathrm{~mm}$ EDTA, $0.2 \%$ SDS, in a $25-\mu$ l reaction containing $20 \mu \mathrm{g}$ of wholecell RNA. If $<20 \mu \mathrm{g}$ of muscle RNA was used, the difference was made up with $E$. coli tRNA. After hybridization, the reaction was diluted $1: 20$ with $0.2 \mathrm{M} \mathrm{NaCl}, 0.1 \mathrm{M} \mathrm{LiCl}, 0.01 \mathrm{M}$ Tris- $\mathrm{HCl}(\mathrm{pH} 7.4)$, and $1 \mathrm{~mm}$ EDTA, adjusted to $20 \mu \mathrm{g} / \mathrm{ml}$ in RNase $\mathrm{A}$ and incubated for $20 \mathrm{~min}$ at $30^{\circ} \mathrm{C}$. The reaction was adjusted to $0.7 \%$ SDS and $500 \mu \mathrm{g} / \mathrm{ml}$ proteinase $\mathrm{K}$ and incubated for $30 \mathrm{~min}$ at $37^{\circ} \mathrm{C}$. The nucleic acids were then purified by phenol-chloroform extraction, precipitated with ethanol, and fractionated on a long $(30 \mathrm{~cm})$, denaturing $5.5 \%$ polyacrylamide gel. The endogenous S16 mRNA protects the S16 sequences in the probe from RNase $A$ and a 534-nucleotide RNA is generated. In contrast, the SV-S16 mRNA does not contain the first 31 nucleotides of the S16 mRNA sequence and therefore does not protect all the S16 sequences in the probe from RNase A digestion. Only 515 nucleotides of the probe are protected by the SV-S16 mRNA. The 515- and 534-nucleotide RNAs are easily separated on the above acrylamide gel.

\section{In vitro translation reactions}

Rabbit reticulocyte lysates were prepared from New Zealand white rabbits as described (Jackson and Hunt 1983). Reticulocyte lysates were adjusted to $3 \mathrm{mM}$ GTP (lithium salt), $50 \mu \mathrm{g} / \mathrm{ml}$ of creatine kinase, and $1 \mathrm{mM} \mathrm{CaCl}$ and digested with micrococcal nuclease for $20 \mathrm{~min}$ at $20^{\circ} \mathrm{C}$ immediately before use (Pelham and Jackson 1976). Digestion was stopped by the addition of $2 \mathrm{~mm}$ EGTA. The final concentration of components in the translation reaction was $100 \mathrm{mM} \mathrm{KCl}, 0.5 \mathrm{~mm} \mathrm{MgCl}_{2}, 10 \mathrm{~mm}$ creatine phosphate, $0.1 \mathrm{~mm}$ in unlabeled amino acids, $20 \mathrm{~mm}$ HEPES $\{\mathrm{pH} 7.5$ ), $70 \mu \mathrm{g} / \mathrm{ml}$ of calf liver tRNA, $2 \mathrm{~mm}$ GTP (lithium salt), and $80 \%$ reticulocyte lysate. RNA to be translated in vitro was dissolved in a volume of $\mathrm{H}_{2} \mathrm{O}$ that was $\leqslant 10 \%$ of the final reaction volume, heated to $90^{\circ} \mathrm{C}$ for $30 \mathrm{sec}$, chilled on ice, and added to the translation reaction mixture. Translation reaction mixtures containing RNA were incubated at $30^{\circ} \mathrm{C}$ for 20 min. RNA was isolated as described previously (Bowman and Emerson 1977; Agrawal and Bowman 1987). Under these conditions, incorporation of $\left[{ }^{35} \mathrm{~S}\right]$ methionine into protein was linear for $\geqslant 60 \mathrm{~min}$, and proteins $>200 \mathrm{kD}$ were synthesized as determined by SDS-polyacrylamide gels as described. Similar results were obtained if $1 \mathrm{~mm}$ hemin I or III (Jackson and Hunt 1983) was used instead of GTP.

After incubation at $30^{\circ} \mathrm{C}$ for $20 \mathrm{~min}$, translation reaction mixtures were put on ice and diluted with 6 volumes of ice-cold buffer containing $0.3 \mathrm{M} \mathrm{NaCl}, 10 \mathrm{~mm}$ Tris- $\mathrm{HCl}(\mathrm{pH} 7.4), 10 \mathrm{~mm}$ $\mathrm{MgCl}_{2}$, and $18 \mu \mathrm{g} / \mathrm{ml}$ of cycloheximide before being layered onto sucrose density gradients for analysis. Translation reactions to analyze 80S initiation complex formation contained 0.5 $\mathrm{mg} / \mathrm{ml}$ of anisomycin (Rose and Lodish 1976) and were preincubated at $30^{\circ} \mathrm{C}$ for 5 min before the RNA was added.

\section{Initiation factor supplementation analyses}

Purified rabbit reticulocyte translation initiation factors eIF-1A, eIF-2, eIF-3, eIF-4A, eIF-4B, eIF-4F, and eIF-5A were isolated as described previously (Merrick 1979; Grifo et al. 1982, 1983). The nomenclature proposed in 1989 is used in this discussion (Safer 1989). The amount of each factor added to reticulocyte translation reactions is indicated in the figure legends.

\section{Acknowledgments}

We thank Dr. V. Vance for critically reading the manuscript. This research was supported by grant AR32221 from the National Institutes of Health.

The publication costs of this article were defrayed in part by payment of page charges. This article must therefore be hereby marked "advertisement" in accordance with 18 USC section 1734 solely to indicate this fact.

\section{References}

Abovich, N., L. Gritz, L. Tung, and M. Rosbash. 1985. Effect of RP51 gene dosage alterations on ribosome synthesis in Saccharomyces cerevisae. Mol. Cell. Biol. 5: 3429-3435.

Agrawal, M.G. and L.H. Bowman. 1987. Transcriptional and translational regulation of ribosomal protein formation during mouse myoblast differentiation. I. Biol. Chem. 262: 4868-4875.

Al-Atia, G.R., P. Fruscoloni, and M. Jacobs-Lorena. 1985. Translational regulation of mRNAs for ribosomal proteins during early Drosophila development. Biochemistry 24: 57985803.

Aziz, N. and H.N. Munro. 1987. Iron regulates ferritin mRNA translation through a segment of its $5^{\prime}$ untranslated region. Proc. Natl. Acad. Sci. 84: 8478-8482.

Baum, E.Z. and W.M. Wormington. 1985. Coordinate expression of ribosomal protein genes during Xenopus development. Dev. Biol. 111: 488-498.

1988. Post-translational control of ribosomal protein L1 accumulation in Xenopus oocytes. Dev. Biol. 126: 141-146

Benoist, C. and P. Chambon. 1981. In vivo sequence requirements of the SV40 early promoter region. Nature 290: 304 310.

Bonneau, A. and N. Sonenberg. 1987. Involvement of the 24$\mathrm{kDa}$ cap binding protein in regulation of protein synthesis in mitosis. J. Biol. Chem. 262: 11134-11139.

Both, G.W., Y. Furuichi, S. Muthukrishnan, and A.J. Shatkin. 1976. Effect of 5'-terminal structure and base composition on polyribonucleotide binding to ribosomes. I. Mol. Biol. 104: $637-658$.

Bowman, L.H. 1987a. rDNA transcription and pre-rRNA processing during the differentiation of a mouse myoblast cell line. Dev. Biol. 119: 152-163.

- 1987b. The synthesis of ribosomal proteins S16 and L32 is not autogenously regulated during mouse myoblast differentiation. Mol. Cell. Biol. 7: 4464-4471. 
Bowman, L.H. and C.P. Emerson, Jr. 1977. Post-transcriptional regulation of ribosome accumulation during myoblast differentiation. Cell 10: 587-596.

-1980. Formation and stability of cytoplasmic mRNAs during myoblast differentiation: Pulse-chase and density labeling analyses. Dev. Biol. 80: 146-166.

Craig, N. and R.P. Perry. 1971. Persistent cytoplasmic synthesis of ribosomal proteins during the selective inhibition of ribosomal RNA synthesis. Nature New Biol. 229: 75-90.

DePhilip, R.M., W.A. Rudert, and I. Lieberman. 1980. Preferential stimulation of ribosomal protein synthesis by insulin and in the absence of ribosomal and messenger ribonucleic acid formation. Biochemistry 19: 1662-1669.

Dudov, K.P. and R.P. Perry. 1984. The gene family encoding the mouse ribosomal protein L32 contains a uniquely expressed intron-containing gene and an unmutated processed gene. Cell 37: 457-468.

Duncan, R.F., S.M. Milburn, and J.W.B. Hershey. 1987. Regulated phosphorylation and low abundance of HeLa cell initiation factor eIF-4F suggest a role in translational control. $J$. Biol Chem. 262: 380-388.

El Baradi,T.T.A.L., C.A.F.M. van Der Sande, W.H. Mager, H.A. Raue, and R.J. Planta. 1986. The cellular level of yeast ribosomal protein L25 is controlled principally by rapid degradation of excess protein. Curr. Genet. 10: 733-739.

Geyer, P.K., O. Meyuhas, R.P. Perry, and L.F. Johnson. 1982. Regulation of ribosomal protein mRNA content and translation in growth-stimulated mouse fibroblasts. Mol. Cell. Biol. 2: 685-693.

Godefroy-Colburn, T. and R.E. Thach. 1981. The role of mRNA competition in regulating translation: IV. Kinetic model. $I$. Biol. Chem. 256: 11762-11763.

Grifo, J.A., S.M. Tahara, J.P. Leis, M.A. Morgan, A.J. Shatkin, and W.C. Merrick. 1982. Characterization of eukaryotic initiation factor 4A, a protein involved in ATP-dependent binding of globin mRNA. J. Biol. Chem. 257: 5246-5252.

Grifo, J.A., S.M. Tahara, M.A. Morgan, A.J. Shatkin, and W.C. Merrick. 1983. New initiation factor activity required for globin mRNA translation. J. Biol. Chem. 258: 5804-5810.

Hammond, M.L. and L.H. Bowman. 1988. Insulin stimulates the translation of ribosomal proteins and the transcription of rDNA in mouse myoblasts. I. Biol. Chem. 263: 1778517791.

Hauschka, S.D., T.A. Linkhart, C.H. Clegg, and G.M. Merrill. 1979. Clonal studies of human and mouse muscles. In Mus cle regeneration (ed. A. Mauro), pp. 211-322. Raven Press, New York.

Hentze, M.W., T.A. Rouault, S.W. Caughman, A. Dancis, J.B. Harford, and R.D. Klausner. 1987. A cis-acting element is necessary and sufficient for translational regulation of human ferritin expression in response to iron. Proc. Natl. Acad. Sci. 84: 6730-6734.

Hershey, J.W.B. 1989. Protein phosphorylation controls translation rates. J. Biol. Chem. 264: 20823-20826.

Huang, W.I., L.J. Hansen, W.C. Merrick, and R. Jagus. 1987. Inhibitor of eukaryotic initiation factor $4 \mathrm{~F}$ activity in unfertilized sea urchin eggs. Proc. Natl. Acad. Sci. 84: 6359-6363.

Jackson, R.J. and T. Hunt. 1983. Preparation and use of nuclease-treated rabbit reticulocyte lysates for the translation of eukaryotic messenger RNA. Methods Enzymol. 96: 5074.

Joshi-Barve, S., W. Rychlik, and R.E. Rhoads. 1990. Alteration of the major phosphorylation site of eukaryotic protein synthesis initiation factor $4 \mathrm{E}$ prevents its associaton with the $48 \mathrm{~S}$ initiation complex. J. Biol. Chem. 265: 2979-2983.

Kafatos, F.C. 1972. The cocoonase zymogen cells of silkmoth: A model of terminal cell differentiation for specific protein synthesis. Curr. Top. Dev. Biol. 3: 121-191.

Kaspar, R.L., W. Rychlik, M.W. White, R.E. Rhoads, and D.R. Morris. 1990. Simultaneous cytoplasmic redistribution of ribosomal protein L32 mRNA and phosphorylation of eukaryotic initiation factor $4 \mathrm{E}$ after mitogenic stimulation of Swiss 3T3 cells. J. Biol Chem. 265: 3619-3622.

Kozak, M. 1988. Leader length and secondary structure modulate mRNA function under conditions of stress. Mol. Cell. Biol. 8: 2737-2744.

- 1989a. Context effects and inefficient initiation at nonAUG codons in eucaryotic cell-free translation systems. Mol. Cell. Biol. 9: 5073-5080.

. 1989b. Circumstances and mechanisms of inhibition of translation by secondary structure in eucaryotic mRNAs. Mol. Cell. Biol. 9: 5134-5142.

Lawson, T.G., B.K. Ray, J.T. Dodds, J.A. Grifo, R.D. Abramson, W.C. Merrick, D.F. Betsch, H.L. Weith, and R.E. Thach. 1986. Influence of $5^{\prime}$ proximal secondary structure of the translational efficiency of eukaryotic mRNAs and on their interaction with initiation factors. I. Biol. Chem. 261: 13979-13989.

Levy, S., D. Avni, N. Hariharan, R.P. Perry, and O. Meyuhas. 1991. Oligopyrimidine tract at the $5^{\prime}$ end of mammalian ribosomal protein mRNAs is required for their translation control. Proc. Natl. Acad. Sci. 88: 3319-3323.

Lodish, H.F. 1976. Translational control of protein synthesis. Annu. Rev. Biochem. 45: 39-72.

Lodish, H.F., D. Housman, and M. Jacobsen. 1971. Initiation of hemoglobin synthesis. Specific inhibition by antibiotics and bacteriophage ribonucleic acid. Biochemistry 10: 23482356.

Lopo, A.C., S. MacMillan, and J.W.B. Hershey. 1988. Translational control in early sea urchin embryogenesis: Initiation factor eIF-4F stimulates protein synthesis in lysates from unfertilized eggs of Strongylocentrotus purpuratus. Biochemistry 27: 351-357.

Maicas, E., F.G. Pluthero, and J.D. Freisen. 1988. The accumulation of three ribosomal proteins under conditions of excess mRNA is determined primarily by fast protein decay. Mol. Cell. Biol. 8: 169-175.

Mariottini, P. and F. Amaldi. 1990. The 5' untranslated region of mRNA for ribosomal protein S19 is involved in its translational regulation during Xenopus development. Mol. Cell. Biol. 10: 816-822.

McMaster, G.K. and G.G. Carmichael. 1977. Analysis of single and double-stranded nucleic acids on polyacrylamide and agarose gels by using glyoxal and acridine orange. Proc. Natl. Acad. Sci. 74: 4835-4838.

Melton, D.A., P.A. Krieg, M.R. Rebagliati, T. Maniatis, R. Zinn, and M.R. Green. 1984. Efficient in vitro synthesis of biologically active RNA and RNA hybridization probes from plasmids containing a bacterial phage SP6 promoter. Nucleic Acids Res. 12: 7035-7041.

Merrick, W.C. 1979. Purification of protein synthesis initiation factors from rabbit reticulocytes. Methods Enzymol. 60: $101-108$

Meyuhas, O. and R.P. Perry. 1980. Construction and identification of cDNA clones for mouse ribosomal proteins: Application for the study of r-protein gene expression. Gene 10: 113-129.

Meyuhas, O., E.A. Thompson, Jr., and R.P. Perry. 1987. Glucocorticoids selectively inhibit the translation of ribosomal protein mRNAs in P1798 lymphosarcoma cells. Mol. Cell. Biol. 7: 2691-2699.

Moldave, K. 1985. Eukaryotic protein synthesis. Annu. Rev. 
Biochem. 54: 1109-1149.

Morley, S.J., T.E. Dever, D. Etchison, and J.A. Traugh. 1991. Phosphorylation of eIF-4F by protein kinase $\mathrm{C}$ or multipotential S6 kinase stimulates protein synthesis at initiation. $J$. Biol. Chem. 266: 4669-4672.

Myers, R.M., Z. Larin, and T. Maniatis. 1985. Detection of single base substitutions by ribonuclease cleavage of mismatches in RNA : DNA duplexes. Science 230: 1242-1249.

Nathan, D. 1964. Inhibition of protein synthesis by puromycin. Fed. Proc. 23: 984-989.

Nomura, M.R., R. Gourse, and G. Baughman. 1984. Regulation of the synthesis of ribosomes and ribosomal components. Annu. Rev. Biochem. 53: 75-117.

Pain, V.M. 1986. Initiation of protein synthesis in mammalian cells. Biochem. J. 235: 625-637.

Pelham, H.R.B. and R.J. Jackson. 1976. An efficient mRNAdependent translation system from reticulocyte lysates. Eur. I. Biochem. 67: 247-256.

Pelletier, J. and N. Sonenberg. 1985. Insertion mutagenesis to increase secondary structure within the 5 ' noncoding region of a eucaryotic mRNA reduces translation efficiency. Cell 40: $515-526$.

Pfarr, D.S., L.A. Reiser, R.P. Woychick, F.M. Rottman, M. Rosenberg, and M.E. Reff. 1986. Differential effects of polyadenylation regions on gene expression in mammalian cells. DNA 5: 115-122.

Pierandrei-Amaldi, P., N. Campioni, E. Beccari, I. Bozzoni, and F. Amaldi. 1982. Expression of ribosomal protein genes in Xenopus laevis development. Cell 30: 163-171.

Pierandrei-Amaldi, P., N. Campioni, P. Gallinari, E. Beccari, I. Bozzoni, and F. Amaldi. 1985. Ribosomal-protein synthesis is not autogenously regulated at the translational level in Xenopus laevis. Dev. Biol. 107: 281-289.

Pierandrei-Amaldi, P., I. Bozzoni, and B. Cardinali. 1988. Expression of ribosomal protein $\mathrm{L} 1$ in Xenopus embryos: Alteration of gene dosage by microinjection. Genes \& Dev. 2: 23-31.

Ray, B.K., T.G. Brendler, S. Adya, S. Daniels-McQueen, J.K. Miller, J.W.B. Hershey, J.A. Grifo, W.C. Merrick, and R.E. Thach. 1983. Role of mRNA competition in regulating translation:Further characterization of mRNA discriminatory initiation factors. Proc. Nat1. Acad. Sci.. 80: 663-667.

Rhoads, D.D. and D.J. Roufa. 1987. A cloned human ribosomal protein gene functions in rodent cells. Mol. Cell. Biol. 7: $3767-3774$

Rose, J.K. and H.F. Lodish. 1976. Translation in vitro of vesicular stomatitis virus mRNA lacking 5'-terminal 7-methylguanosine. Nature 262: 32-37.

Safer, B. 1989. Nomenclature of initiation, elongation, and termination factors for translation in eukaryotes. Eur. $J$. Biochem. 186: 1-3.

Southern, P.J. and P. Berg. 1982. Transformation of mammalian cells to antibiotic resistance with a bacterial gene under the control of the SV40 early region promoter. I. Mol. Appl. Genet. 1: 327-341.

Steel, L.F. and A. Jacobson. 1987. Translational control of ribosomal protein synthesis during early Dictyostelium discoideum development. Mol. Cell. Biol. 7: 965-972.

Theodor, L., D. Peleg, and O. Meyuhas. 1985. P31, a mammalian housekeeping protein encoded by a multigene family containing a high proportion of pseudogenes. Biochim. Biophys. Acta 826: 137-146.

Tsay, Y.-F, J.R. Thompson, M.O. Rotenberg, J.C. Larkin, and J.L. Woolford, Jr. 1988. Ribosomal protein synthesis is not regulated at the translational level in Saccharomyces cerevisiae: Balanced accumulation of ribosomal proteins L16 and rp 59 is mediated by turnover of excess protein. Genes \& Dev. 2: 664-676.

Wagner, M. and R.P. Perry. 1985. Characterization of the multigene family encoding the mouse S16 ribosomal protein: Strategy for distinguishing an expressed gene from its processed pseudogene counterparts by an analysis of total genomic DNA. Mol. Cell. 5: 3560-3576.

Warner, J. 1977. In the absence of ribosomal RNA synthesis, the ribosomal proteins of HeLa cells are synthesized normally and degraded rapidly. J. Mol. Biol. 115: 315-333.

Warner, J.R., G. Mitra, W.F. Schwindinger, M. Studeny, and H.M. Fried. 1985. Saccharomyces cerevisiae accumulation of yeast ribosomal proteins by modulating mRNA splicing, translational initiation, and protein turnover. Mol. Cell. Biol. 5: 1512-1521.

Weidemann, L.M. and R.P. Perry. 1984. Characterization of the expressed gene and several processed pseudogenes for the mouse ribosomal protein L30 gene family. Mol. Cell. Biol. 4: $2518-2528$. 


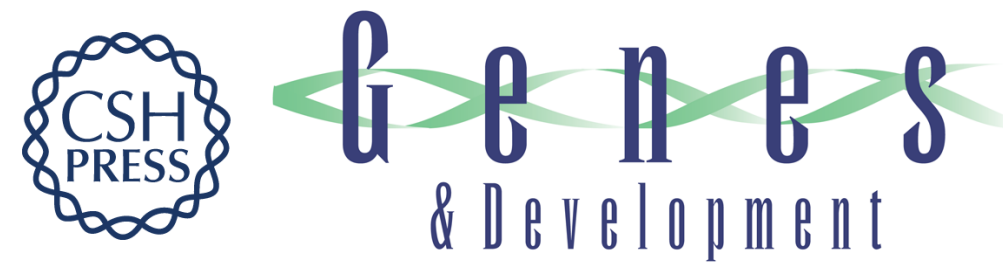

\title{
Sequences mediating the translation of mouse S16 ribosomal protein mRNA during myoblast differentiation and in vitro and possible control points for the in vitro translation.
}

\author{
M L Hammond, W Merrick and L H Bowman
}

Genes Dev. 1991, 5:

Access the most recent version at doi:10.1101/gad.5.9.1723

\section{References This article cites 69 articles, 35 of which can be accessed free at: http://genesdev.cshlp.org/content/5/9/1723.full.htmI\#ref-list-1}

\section{License}
Email Alerting Service

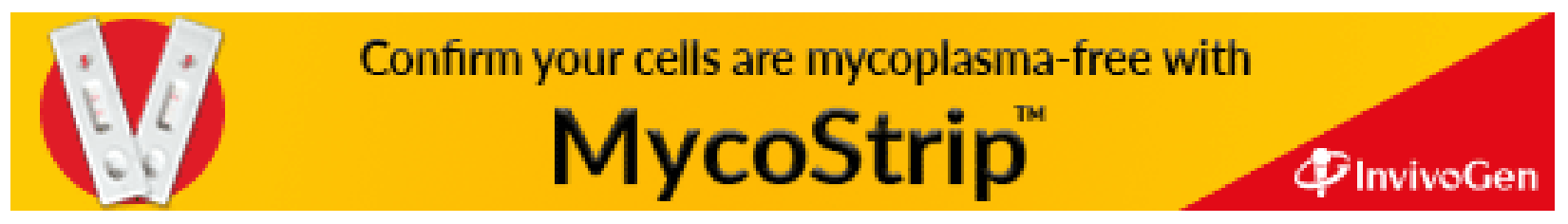

